\title{
BEYOND THE DIGRESSION: AMMIANUS MARCELLINUS ON THE PERSIANS
}

\begin{abstract}
Ammianus Marcellinus' information and knowledge of the Sasanian Persians is often criticised for being stereotypical and reliant on traditional tropes and ideas. This is a result of a scholarly focus on the historian's long Persian digression, which is based predominantly on ethnographic traditions and older writers. When the focus is switched instead to the wider narrative of the Res Gestae the information Ammianus Marcellinus presents of the Persians and their empire is usually accurate and reliable, and can be corroborated by Roman and Sasanian sources. Beyond the digression we can find useful knowledge on the Persian army, kingship, ideology, frontiers and cultural permeability can be found.
\end{abstract}

Keywords: Ammianus Marcellinus, Persia, Sasanian, Persian, Res Gestae

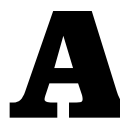

mmianus Marcellinus' knowledge of the Persian Empire, its people, politics, history and geography has been much discussed by scholars, who have traditionally been critical of its stereotypical nature. ${ }^{1}$ It is arguably because of this criticism that recent works on the Persians in the Res Gestae have concentrated on the image Ammianus presents of the Persians rather than the veracity of his information. For example, in "Ammianus Marcellinus' Image of Sasanian Society" Drijvers states that 'I will not so much focus on the historical veracity of Ammianus' account of the SasanianRoman conflicts and the information he presents about the Persians, but on the image which Ammianus gives of the Persians and Sasanian society'. ${ }^{2}$ Likewise, in his study of the final part of Ammianus Marcellinus' description of Julian's Persian campaign in 363, in which lots of useful and important information on the Persians can be found, Smith specifically states 'My concern here, though, is not with the historical accuracy of Ammianus' account; and the significance of his personal experiences and observations as a participant will figure only tangentially'. ${ }^{3}$ In these works it is generally accepted that the image of the Sasanian Persians in the Res Gestae is 'complex and nuanced'. ${ }^{4}$ It is the aim of this paper, therefore, to take a systematic approach to Ammianus' information on the Sasanian Persians and their empire to analyse how factually reliable his complex and nuanced image of the Persians is.

Although Ammianus is generally viewed as reliable and trustworthy on Roman-Sasanian relations this trust has not extended to his knowledge

\footnotetext{
Perhaps the most severe critic in this regard, and the instigator of much of this criticism, was Mommsen's influential article 'Ammians Geographica' (1881).

2 (2006) 45.

3 SMITH 199989.

4 DRIJVERS, 2006: 65.
}

\section{Craig Morley}

University of Liverpool,

craig.morley@outlook.com

DOI: $10.14795 /$ j.v3i4.199

ISSN 2360 - 266X

ISSN-L 2360 - 266X 
of the Persians. ${ }^{5}$ This is despite the fact he had vast personal experience of the Persians and their empire which granted his writing a degree of authority. The history of this 'former soldier and a Greek' ${ }^{6}$ covers the period from A.D 358-378; as such, his narrative includes some of the most important events in Roman-Persian relations during this era. Namely, Shapur II's invasion of the Roman Empire in $359^{7}$ and Julian's Persian campaign of $363 .^{8}$ Even more importantly, Ammianus was an eye-witness to many of the events he describes. For instance, he was trapped in Amida during Shapur II's siege of the city in $359^{9}$ and he served under Julian during the emperor's ill-fated invasion of the Persian Empire in 363. He experienced and witnessed many different aspects of the Persian Empire; its customs, traditions, lands and cities. Thus, phrases such as 'I, myself have crossed' and 'I, myself have seen' are common throughout his narrative. ${ }^{10}$

Despite the entrenched sense of authority and veracity these personal experiences give his work, Ammianus' inclination to describe his own activities in his narrative has been criticised as showing a preference for personal reminiscences and tall-tales rather than sober historical analysis. ${ }^{11}$ However, being an eye-witness to the events described was regarded as an essential qualification of history-writing by the Romans. ${ }^{12}$ Ammianus himself certainly believed the fact he observed these events himself was an important aspect of his qualification as a historian. ${ }^{13}$ Yet, Ammianus does not overtly or over-enthusiastically enforce himself as a deciding figure in how these events developed. Indeed, it has even been claimed that despite his personal involvement in many of the events described Ammianus rarely includes his own personal experiences in the wider narrative. ${ }^{14}$ As Blockley has pointed out, Ammianus' narrative of the 359 invasion, in which he was personally and directly involved, only mentions his own activities four times, while during the siege of Amida Ammianus changes 'I' to 'we' for the duration of the battle. ${ }^{15}$ Indeed, the fact that Ammianus regularly describes himself hiding or running away from danger underlines his propensity not exaggerate his own role. ${ }^{16}$ Therefore, these personal accounts should not be considered a weakness or flaw in Ammianus' history-

\footnotetext{
5 DRIJVERS 1998, 269: 'Ammianus' information on the historical events of his time is trustworthy'. JONES 1964, 116 likewise finds him reliable. While Austin (1979) finds Ammianus both reliable and knowledgeable on military matters. However, there are historians who counter this view and instead highlight his inconsistency and unreliability. SEECK 1906 was arguably one of the earliest to voice criticism of Ammianus, but more recent studies by PASCHOUD 1992, BLECKMANN/WEISWEILER 2014 have criticised the historian. BARNES 1998 took this even further by stating that Ammianus' literary technique was more suited to historical misrepresentation than truth. Likewise, ROSEN 1970, 10-66 believed the historian's aims were more literary than historical.

631.16 .8

$18.4-19.9,20.2$

$83-25$.

9 Ibid. 19.1-8.

$10 \quad 23.6 .20,27$

11 MATTHEWS 1983, 32; ROSEN 1970.

12 KELSO 1998, 37. DRIJVERS 2006, 45, states that Ammianus is traditionally believed to be well informed due to his personal involvement in major events.

13 23.6, 15.1.1.

14 DRIJVERS 2006, 65.

$151988,245$.

$16 \quad 18.6 .10,19.8 .7$
}

writing but a strength. ${ }^{17}$ As shall be shown below, it was from his own personal eye-witness accounts that Ammianus' most reliable and credible information about the Persians can be found.

Indeed, that Spectatus, an ambassador who had likewise travelled the Persian Empire, was said to have seen 'much [Persian] land and mountains and rivers... [to have witnessed] the way of life of the Persians, the customs and laws by which they live [and] to have seen the king himself and the jewels with which he was adorned' in his travels reinforces the benefits of similar experiences to Ammianus. ${ }^{18}$ Related to his personal experiences, Ammianus' position as a protector in the Roman army ensured he was in an invaluable position to gain information from his contacts in the military, such as Ursicinus, as well as access to the reports of scouts, spies and deserters. ${ }^{19}$ Additionally, the fact that he was from the eastern provinces, and a native of Antioch, the habitual battle-ground of Roman and Persian armies, would likely have resulted in Ammianus obtaining some general knowledge, at least of the military capabilities, of the Persians. ${ }^{20}$

Nevertheless, Ammianus' digression on the Persians (23.6) has quite rightly received criticism from scholars for its stereotypical presentation of the Persians, their empire and way of life..$^{21}$ Matthews has highlighted the similarities found in Ammianus' Persian digression and the works of his predecessors, noting that: 'The digression, like others, bears more traces of what Ammianus had read than of what he had seen'. ${ }^{22}$ In this regard, Feraco has listed Justin, Solinus, Pliny the Elder, Herodotus, Strabo, Eratosthenes, Cassius Dio and Ptolemy as earlier historians whose influences can be found throughout Ammianus' digression..$^{23}$ It is certainly true that Ammianus' description of the Persians in his digression is often indistinguishable from the way much earlier historians described the Medes, Achaemenids and Parthians that came before them. ${ }^{24}$ Indeed, Ammianus uses the term 'Parthians' interchangeably with 'Persians' when talking about the

\footnotetext{
KELLY 2008, 65-66 also agrees that Ammianus' personal accounts strengthen his work. In his article 'In Support of Ammianus; Veracity' AUSTIN 1973, 331-332 uses the example of the historian's exploits in Corduene to defend the information in his personal accounts. MATTHEWS 1989, 48, also supports Ammianus' account in this example. Although it has been criticised by WEISWEILER 2014, 24-39.

18 Libanius Ep. 331.1. Although, it must be noted that travelling Persian lands in a time of peace likely granted Spectatus the chance to view more normalised Persian ways of life and customs.

19 CHAUMONT 1989. For the responsibilities of a Roman soldier of this rank see MATTHEWS 1989, 74-80; AUSTIN 1979, 74-80; TROMBLEY 1999, 17-28. 20 On his Antioch origins see: THOMPSON 1947, 1; WALLACE-HADRILL 2004, 14. For more information on Ammianus' background see MATTHEWS 1994.

21 The Persian digression can be found at 23.6.

1989: 14. Of this statement TEITLER 1999, 217 says he agrees wholeheartedly.

23 2004: 9-21. DRIJVERS 1999, 202 cautions against overconfidence when trying to identify exactly what sources Ammianus used and where exactly they influenced his work.

${ }^{24}$ Although TEITLER 1999 acknowledges this trend, especially in relation to Herodotus, he also highlights that the relationship between the two historians was more complex, by noting and explaining instances where Ammianus directly contradicts information given by Herodotus. For example, TEITLER 1999, 220 notes that whereas Herodotus states the Persians were fond of drinking wine and never made any major decisions without it Ammianus says
} they only drank in moderation. 
Sasanian Persians. ${ }^{25}$ Alongside utilising these terms it has been noted that Ammianus never refers to the Persians of the third century onwards as Sasanians, which has caused some scholars to question if he was aware of the change in power between the Parthian Arsacids and Sasanians in $224 .{ }^{26}$ Such similarities with earlier works should be no surprise, however. Ammianus himself specifically references the 'writers of old'. ${ }^{27}$ The historian evidently intended his digression to emulate his predecessors to some degree, as a way of displaying his knowledge of these earlier historians. ${ }^{28}$ Indeed, the wider narrative of the Res Gestae is replete with references to earlier Greek writers and historical works. ${ }^{29}$ In a bid to show his audience how knowledgeable he was of the Persians, or at least of their literary stereotype, the digression was split into distinct sections, each focused on a different aspect of the Persian Empire; a historical introduction, a geographical introduction, description of the provinces of the empire and finally a description of the Persians' customs. ${ }^{30}$ Despite the limitations of this digression, the fact that it was longest ethnographic and geographic digression in Ammianus' work and that, unlike the others, it was much more distinct and self-contained can be suggested to show Ammianus was aware that the Persian Empire was Rome's most important neighbour at this time. ${ }^{31}$

Although Ammianus overtly displays the traditional negative Roman view of the Persians, describing them as savage, treacherous and deceptive. ${ }^{32}$ However, alongside this traditional hostility Ammianus also presents a complex and nuanced picture of the Sasanian Persian. This less openly hostile view is evident in comparisons with the majority of Ammianus' contemporaries, and in comparison to the way he describes Rome's other neighbours. ${ }^{33}$ Ammianus' belief that the Roman deceiving, betrayal and slaughter

\footnotetext{
25 25.8.9-10.

26 CHAUVOT 1992, 115-25 poses this question about Ammianus' knowledge of the Sasanian take-over. This lack of detail is highly surprising, and highly damaging to Ammianus' reputation as a reliable source on the Sasanian Persians, given that the change of power from the Parthians to the Sasanians is mentioned by Herodian (6.2), Cassius Dio (80.3.4) and Zosimus (1.18.1). Although, as DRIJVERS 1999, 195 has stated 'as a historian Ammianus probably knew about the takeover by the Sassanids, he omits referring to it because the Romans usually do not distinguish between a Persia ruled by the Arsacids and a Persia ruled by the Sassanid dynasty'.

27 23.6.30.

28 BARNES 1990 has likewise argued Ammianus' predecessors played an important role in the composition of his work. Ammianus' desire to show his familiarity with earlier writers and historians is also evident in his frequent imitation of Juvenal, author of the Satires, in his digressions on the city of Rome (REES 1999; SMITH, 1994). These Roman digressions can be found at 14.6.1-26 and 28.4.1-35.

29 During the siege of Amida Ammianus twice recalls events from Homer's Iliad. First, he likens the death of the Chionitae prince and the subsequent battle over his body to battle over Procolus's body during the Trojan War and, secondly, compares the feats of the Gallic legion's sally against the Persian besiegers to the killing of 'Rhesus and his Thracians in their sleep before the walls of Troy' (19.17-9, 19.6.10-11). Likewise, he recalls Thucydides' account of the plague which struck Athens during the Peloponnesian War (19.4).

30 DRIJVERS 1999, 194.

31 This is a point ROHRBACHER 2002, 208 concurs with. The Res Gestae also has ethnographic digressions on the Arabs (14.4.1-7), the Huns and Alans (31.2.1.-25), as well as geographic digressions on Gaul (15.9-12), Egypt (22.15-6), the Black Sea (22.8) and Thrace (27.4.1-4).

32 For example, he has Julian call the Persians goats (24.8.1). Comparing barbarian peoples to animals was a regular trope of Roman historians: Goths (31.15.2). Scythians (22.8.42).

33 TEITLER 1999, 216.
}

of a group of Saxons was acceptable as barbarians deserve such treatment simply because they are barbarians does not have a corresponding Persian example. ${ }^{34}$ Ammianus' more nuanced presentation of the Persians is also evident in his account of the invasion of 359, where Shapur II is given a prominent role, and his good planning and strong leadership is contrasted with Roman inertia and corrupt incompetence. ${ }^{35}$ Likewise, earlier in his work the historian indicates that Julian regarded the Persians as a 'worthier' enemy then any of Rome's other neighbours. ${ }^{36}$

It is necessary to explain why a historian with vast first-hand experience and a more nuanced view of the Persians chose to represent them in such a stereotypical manner in his digression. That Ammianus was a classicising historian who desired to emulate the likes of Herodotus and Thucydides, and to fulfil the expectations of his Roman audience arguably played the underlying role in the development and nature of his digression. ${ }^{37}$ Ethnographic digressions were a traditional aspect of Roman historiography, and had been an integral part of Greco-Roman history since Herodotus. They were fully expected by Roman audiences, whom Ammianus would not have wanted to disappoint. ${ }^{38}$ Indeed, when talking of the various digressions in Ammianus' work it has been stated that '[a]s an historian writing in the classical tradition, Ammianus was obliged to include in his work digressions of various sorts'. 39

Similarly, during the fourth century, when Ammianus was writing, the Roman idea of the Persian Empire as an alter orbis, a world that was completely different and alien to the Roman Empire, was well-entrenched..$^{40}$ In this regard, Agathias' comment that anything opposite to one's own culture 'is deemed deplorable, contemptible, and unworthy of serious consideration' is pertinent. ${ }^{41}$ From this statement, it can be inferred that the Romans believed anything that was considered completely different to their own way of life and culture was unworthy of true study and understanding. ${ }^{42}$ 34 28.5.1-7. For this interpretation of this passage see HEATHER 1999, 234. 5 18.4-19.9. Blockley 1988, 248 also argues this contrast as the underlying reason for the development of the invasion. However, it is possible, and must be acknowledged, that this contrast between the energy of Shapur and the inertia of the Roman army may have been a way to attack Constantius due to the perceived slights and slanders Ammianus believed that were targeted against his patron Ursinicus by the corrupt officials within Constantius court (21.16.16).

$36 \quad 22.7 .8$.

On Ammianus as a classicising historian see: TREADGOLD 2007, 51-78; WILSHERE 1973; KALDELLIS 2004, 3-19. Although, it is widely acknowledged that Ammianus' work was a continuation of Tacitus' history, it has been argued that the Ammianus did not actively seek to emulate his famous Roman predecessor, but was more influenced by Greek historical traditions, such as those found in Herodotus and Thucydides: BARNES 1998, 65-70; 1990, 63-65; MATTHEWS 1989, 32; DRIJVERS 1998, 269. In contrast, FORNARA 1992 and KELLY 2008, 66 argue that Ammmianus did not have first-hand knowledge of the Greek historians himself but got his information from Latin compilations and intermediaries of the original works of Herodotus and Thucydides.

38 DRIJVERS 1999, 193. On the function and importance of Ammianus' digressions see RICHTER 1989. That the Res Gestae includes 31 digressions shows the historians' eagerness not to disappoint his audience in this regard.

39 DRIJVERS 2006, 59. Other digressions in Ammianus' work focus on earthquakes (17.7.9-14), eclipses (20.3.2-12) and the plague (19.4.2-8), as well as the ethnographic and geographic digressions mentioned above.

40 On the Roman understanding of the Sasanian Persians as the heirs to the Achaemenid Persians see: Cassius Dio (80.4.1) and Herodian (6.2.1-2).

412.23 .8 .

42 This also certainly links with ISAAC's 2004 and WALBANK's 1983, 66 
This is even more relevant when emphasis is placed upon the Roman perception of the Sasanian Persians as heirs to the Achaemenid Empire, which Ammianus Marcellinus himself explicitly mentions, ${ }^{43}$ and is contrasted with the Roman view of themselves as the heirs of Alexander the Great, the conqueror of the Achaemenid Empire. ${ }^{44}$ Indeed, during this period the ideal of Alexander-emulation, imitatio Alexandri, was increasingly prevalent and important to Roman emperors. ${ }^{45}$ In this regard, nothing could be more different to those who regarded themselves as the heirs of Alexander than a people who expressed themselves as the heirs of the Achaemenids, Alexander's arch-enemies.

Thus, due to the circumstances and the conditions under which he wrote, Ammianus likely felt compelled to present the Sasanian Persians in his digression in a stereotypical manner, to recall the entrenched traditions and ideas of the Persians that his audience would have been familiar with and would have expected. ${ }^{46}$ He was simply trying to conduct his ethnographical digression in a style that would be most pleasing and most expected by his Roman audience, by highlighting and emphasising the traditional differences between the Romans and Persians. ${ }^{47}$

As a result, most of Ammianus Marcellinus' more nuanced information on the Persians does not come from this digression but from other sections of his narrative, where it can be found almost inconspicuously amongst tales of Persian armies, shahs and cities. Scholarship on Ammianus' knowledge of the Persians has thus far focused argument that Roman racism was based on culture rather than race. Scipio's discussion with Laelius about the barbarity of Romulus in Cicero's Republic (1.37.58) is evidence of this.

43 17.5.2.

44 This Achaemenid heritage has been much discussed and debated by scholars, more information of this debated can be found on P.22.

${ }_{45}$ For this oppositional ideology see: DIGNAS/WINTER 2007, 1; SPENCER 2002. The connection between the resurgence of imitatio Alexandri as a response to the rise of the Persian Empire is evident in the evocations of Alexander's legends by Roman emperors, or at least Roman writers writing about Roman emperors, from 224 onwards (Diocletian: Malalas 12.39; Constantine: Euseb. VC. 4.15.1; Julian: Amm. Marc. 24.4.26-7; Honorius: Claud. IV Cons. Hon. 257-8, 379). This connection has also been acknowledged by SMITH 2011, 50. Trajan (Dio 68.29.1); Caracalla (Dio. 77.7.1); Alexander Severus (SHA Sev. Alex. 5.1-2, 25.9) were all compared to Alexander after launching eastern campaigns. On the overall importance of the memory and legend of Alexander to the Romans see SPENCER 2002. However, the most famous, and debated, example of this drive to emulate Alexander was Julian, whose 363 campaign was presented by many contemporary and later Roman writers as an attempt to emulate Alexander's conquest of the Achaemenid Empire (Soc. HE 3.21; Greg. Naz. Orat. 5.14; Eunap. fr. 28.3). Those who support the idea that Julian actively sought to emulate Alexander include ATHANASSIADI-FOWDEN 1981, 192; 224-5 and WIRTH 1978, 455-68. Those who argue this idea was more likely the result of Christian attacks on Julian, who tried to malign the pagan emperor as a means of showing his arrogance and folly include LANE FOX 1997 and SMITH 2011.

${ }_{46}$ This trend has also been recognised in Ammianus' stereotypical presentation of the Huns in his ethnographic digression of this more nomadic group, which focuses on traditional ideas of their savagery and barbarity, as this is what his audience both wanted and expected, KING 1987 [1995].

47 This view is also supported by DRIJVERS 2006, 66; 2011a, 71-72 and WIEDEMANN 1986, 201, who argue that audience expectations affected Ammianus presentation of Rome's other neighbours. Once again, this is also evident in the stereotypical presentation of the Huns in Ammianus' digression on them, KING 1987 [1995]. ROSEN 1982, 85 and RICHTER 1989, 218 argue a slightly different angle, by stating that Ammianus' Persian digression was designed to highlight to his Roman audience their own faults and in contrast with the virtues of their Persian enemies. However, this still agrees with the general belief that the digression was not designed for full veracity but rather for another specific purpose. on the digression, and this may account for his mixed reputation for accurate and reliable information on the Persians. For example, Drijvers states that 'A large part of this paper will be dedicated to the long excursus on the Persian Empire, including its ethnographic description of the Persians'. ${ }^{48}$ Although Drijvers does include analysis on the image of the Persians found throughout the Res Gestae's narrative alongside his focus on the digression it is the aim of this paper to expand on this by taking a systematic approach to the information found in the wider narrative.

When Ammianus states that he would improve upon the information about the Persians presented by his predecessors, it is in these passages, not the digression itself, which we must look for this improved information. Beyond the digression Ammianus provides useful and frequently overlooked information on various political and administrative aspects of the Persian Empire, which feature alongside genuine attempts to understand its history and institutions: it is these passage that this study will focus. Yet, before evaluating this knowledge it is important to remember that 'Ammianus wrote the history of his own time'. ${ }^{49}$ Therefore, his work must only be judged on the conditions that existed in the Persian Empire during the time he was writing and not to cast doubt on any claims or information presented in the Res Gestae that do not match up with later periods of Persian history, of which Ammianus could not possibly have been aware.

\section{AMMIANUS ON THE PERSIAN ARMY}

The army (spāh) was the Persian institution with which Ammianus was most familiar, having fought against it first under Ursinicus in 359 and then again under Julian in 363. It is therefore no surprise that information about the Persian army features frequently throughout the Res Gestae. It is for this reason, as well as Ammianus' own experience in the Roman army, that his information on the Persian military is largely believed to be reliable by modern historians. ${ }^{50} \mathrm{On}$ the Persian army, Ammianus states:

They rely especially on their cavalry, in which all their nobility and men of mark serve. Their infantry are armed like gladiators and obey orders like soldiers' servants. ${ }^{51}$

The Persians opposed us with squadrons of cuirasses drawn up in such serried ranks that their movements in their close-fitting coats of flexible mail dazzled our eyes, while their horses were protected by housings of leather. They were supported by detachments of infantry who moved in compact formation carrying long, curved shields of wicker covered in raw hide. Behind them came elephants looking like moving hills. Their huge bodies threatened destruction to all who approached, and past experience had taught us to dread them. ${ }^{52}$

Ammianus' description of the heavily armoured Persian cavalry in these two passages certainly aligns with the later Arabic writer Tabarīs similar description of them as
$482006,45$.
49 DRIJVERS 1998, 268
50 We have already seen how AUSTIN 1979 believed Ammianus to be reliable on military matters.
5123.6 .83 .
24.6 .7 . 
armed and armoured to the teeth. ${ }^{53}$ The Phoenician novelist Heliodorus, author of the Aethiopica, writing in either the third century or second half of the fourth century, also describes the Persian cavalry as heavily armoured. ${ }^{54}$ Even more telling, the rock relief of Khusro II at Taq-i Bustan shows the shah astride his armoured horse wearing full mail, an image which clearly recalls the heavily armoured Persian cavalry described by Ammianus above. ${ }^{55}$ Likewise, the historian's comment that the nobility served in the cavalry can be substantiated by the fact that only the wealthiest individuals would likely have been able to afford the amount of armour and arms that was needed to serve in this elite unit. ${ }^{56}$

The focus on the cavalry in the above descriptions of the Persian army creates the impression that it was these elite units which formed the core of the späh and that Persian battles were decided by the success or failure of their mailed cavalry. Modern historians such as Wiesehöfer and McDonough certainly agree with this, stating that, 'combats were mainly decided by a concentrated attack of the cavalry' and that the 'aristocratic cavalry formed the backbone of the Sasanian armies'. ${ }^{57}$

In the second passage quoted above, Ammianus mentions the use of elephants in Persian armies, stating that they were used by Shapur II in the defence of Ctesiphon in 363. ${ }^{58}$ Elsewhere in his narrative Ammianus informs us that the Persians made use of elephants during the siege of Amida, ${ }^{59}$ in another battle with Julian, ${ }^{60}$ and in a surprise attack against Jovian, an account that is supported by Zosimus. ${ }^{61}$ The use of elephants in the Persian army is corroborated by Persian and other eastern sources. Tabari informs us that elephants were used by the Persians as early as the reign of Shapur I, who used them to capture Hatra. ${ }^{62}$ Likewise, Persian rock reliefs, such as that at Taq-i Bustan, which depicts the use of elephants in the army of Khusro II, confirm the use of elephants in Persian armies. ${ }^{63}$ Persian use of elephants can also be found in other Roman sources. For example, Procopius, himself a veteran of RomanPersian conflicts, also mentions the Persian army deploying elephants, especially in siege-warfare: a fact that would corroborate Ammianus' statement that they were used during the siege of Amida. ${ }^{64}$ Ammianus' information on how elephants were used in battle, being 'loaded with men', is also validated by similar accounts in the works of Procopius

\footnotetext{
53 964. Tabarī is describing the army of Khusro I (531-579) here.

54 Aethiopica 9.15.1-6.

55 GHIRSHMAN 1962, fig 235. For modern discussions of the Persian mailed cavalry see BIVAR 1972; MICHALAK 1987, 73-86; CAMPBELL 1999, 339.

56 This is supported by PAYNE 2016, 527, who states that 'Iranian elites were expected to participate in military campaigns and even to man the most forward, exposed flanks of the cavalry.'

57 WIESEHÖFER 1996, 198; MCDONOUGH 2011, 299.

58 24.6.7. It must be noted that RANCE 2003, 365 argues the use of elephants against Julian throughout his invasion of Persian territories was a consequence of sheer need and desperation rather than any military norm.

$59 \quad 19.2 .3$

$60 \quad 25.1 .14$.

61 25.6.2-3; Zos. 3.30.2-3.

62 829. Tabarī (878) also informs us that Peroz made use of elephants in his campaign against the Hephthalites and again during their later wars against the Arabs (1031).

63 DARYAEE 2008a, 46.

64 Proc. BG. 3.14.10, 8.14.32-37.
}

and Agathias, who similarly describe Persian war-elephants carrying soldiers on their backs. ${ }^{65}$

Alongside cavalry-actions, siege-warfare is the most common activity of the Persian army in the Res Gestae. Throughout his narrative Ammianus provides insights into the siege-tactics and siege-engines utilised by the Persians in their conquests of Roman cities, particularly during his account of the siege of Amida in 359. For example, Ammianus informs us that the Persians employed 'mantlets', 'penthouses', armoured towers topped with artillery and earthwork ramps in their attempts to capture the city. ${ }^{66}$ That these tactics and siege-engines were reminiscent of their Roman counterparts was not merely Ammianus forcing his own experience of the Roman army onto the Persians but was due to the fact the Persian army actively 'utilised Roman know-how when it came to the use of siege-weapons' ${ }^{67}$ This idea of Persian skill in siege-warfare is certainly supported by the later Byzantine military manual, the Strategikon, which states that '[the Persians] are awesome when they lay siege'. ${ }^{68}$ The fact that the Strategikon is attributed to Maurice, the Byzantine ruler who aided Khusro II in winning the Persian throne in the sixth century gives this statement considerable credence ${ }^{69}$ More importantly, Ammianus' image of strong Persian siege-warfare is supported by the fact that the Persians were able to successfully besiege and capture many heavily defend and fortified cities, both Roman and nonRoman throughout their history.

Elsewhere, Ammianus makes clear that the Persians made use of foreign troops to boost their military capabilities. The audience is informed that the newly cowed Chionitae, Gelani, Albani and Segestani all provided allied contingents for Shapur II's invasion of the Roman Empire and that they were all present during the siege of Amida. ${ }^{70}$ Similarly, during Ammianus' narration of Julian's Persian campaign in 363 he records that the Roman army battled against 'Saracens' who fought alongside the Persian army. ${ }^{71}$ This information is certainly supported by the fact that Persia's Arab allies, namely the Nasrids of al-Hira, played a fundamentally important role in the defence of the Persian Empire's southern frontier. ${ }^{72}$ Although this may seem relatively superficial, given that the Romans and most other ancient imperial polities utilised foreign troops in their military endeavours in some capacity, it is true nevertheless, and is therefore another example of Ammianus providing veracious information on the Persians. ${ }^{73}$

\footnotetext{
6 19.2.3. Proc. BG. 8.13.4, 8.14.35; Agathias 3.27.3. For more discussion on Persian use of elephants in the army see RANCE 2003, CHARLES 1998; 2007 and DARYAEE 2016.

66 19.5.1, 19.6.5-6, 19.7.2

7 DARYAEE 2008a, 46. LEE 2013 also agrees with Persian imitation of Roman military techniques.

68 Maurice, Strategikon 11.1.

69 Although Maurice's authorship has been the point of some the debate, the Strategikon does indeed come from the same period as the Byzantine emperor, between the end of the sixth century and the beginning of the seventh century. For more discussion on this military manual, and its authorship and date of composition see WHITBY 1988, 242.

70 18.6.22; 19.2.3.

24.2.4.

2 SHAHID 1989, 478; BOSWORTH 1986. The importance of Persia's allies, particularly the Nasrids is also confirmed by the fact that Bahrām V was sent to be raised at their court in al-Hira (Tabarī 854-5; Shahnama 2078-80).

73 Older empires such as the Assyrians and Achaemenids made use of Arab
} 


\section{AMMIANUS ON PERSIAN KINGSHIP}

When assessing Ammianus Marcellinus' information on Persian kingship it is important to remember that it was not static; Persian kingship changed and adapted to different circumstances as and when they arose. Indeed, a comparison between the kingship of Ardashir I, the founder of the empire, and Yazdard III, the empire's last effective ruler, would reveal arguably more differences than similarities. ${ }^{74}$ Consequently, when judging Ammianus' knowledge, care is needed to not judge it against our own information on later Persian kingship, and to focus only on its nature during the period in which the historian wrote.

Despite the fact that Ammianus only had the chance to write about one shah, Shapur II (241-272), the nature of Persian kingship features heavily throughout the Res Gestae. This attention is likely linked to the expectations of his audience. The Roman Emperor and the Persian Shah were the most obvious similarity, and difference, between the two empires; therefore, a Roman audience would likely have been eager to learn what they could of the Persian ruler. Likewise, as a classicising historian Ammianus was inherently interested in wars and foreign relations, in which Shapur played a large role during the period covered by the Res Gestae.

The Persians hailed [Shapur] as Saanshah and Peroz, titles which signify 'king of kings' and 'conqueror' in war.

One of the most readily apparent aspects of Ammianus' information on the Persian shahs, evident from the passage above, is his knowledge of royal titulature. He informs us that during the siege of Amida Shapur was extolled by his troops with the titles of 'Saanshah' and 'Peroz', even more tellingly Ammianus was aware of what both of these titles meant; 'king of Kings" and 'conqueror in war'. ${ }^{75}$ That such titles were used by shahs themselves is evident from Shapur I's Res Gestae divi Saporis at Naqs-i Rustam and is generally acknowledged by scholars. ${ }^{76}$

As the title Peroz suggests, Persian kingship was highly militaristic: military reputation and success was a crucial part of a shah's legitimacy and right to rule. ${ }^{77}$ Indeed, it has been stated that 'Central to Sasanian royal ideology was the idea of the king as a warrior' and 'despite significant changes over its four-hundred year existence [the Persian Empire] remained wedded to the formula of the king as the bringer of justice, order, and peace through military victory'. ${ }^{78}$

allies, BOSWORTH 1983; 1986, while the Romans made extensive use of foreign allies, both Arabs and others, FISHER 2008, 313; SARTRE 2005, 360. Indeed, it has been stated that 'from at least the fourth century onward, the Sasanians came to employ large numbers of auxiliary troops to expand their offensive capabilities': MCDONOUGH 2011, 300.

${ }^{74}$ As DARYAEE 2008b, 60 has rightly pointed out, the concept of Persian kingship in the third century was totally different to that of the sixth century. 75 19.2.11.

76 SKZ $\$ 1$. HUYSE 2006 has recently shown that these titles were used extensively by Shahs in the third and fourth centuries. Likewise, SHAYEGAN 2013, 806 argues that the title King of Kings represented the 'core of Sasanian titulature during this period'.

77 RUBIN 2000, 13; 2004, 244. HOWARD-JOHNSTON 2010, 4 has argued that the attacks against the Roman Empire during the reigns of Narsēh and Kavād were primarily to win the new incumbents of the Persian throne a military reputation and legitimacy that they otherwise lacked. Likewise, BÖRM 2015, 266 suggests that Ardashir II gained the throne ahead of Shapur II's son due to the part he played in the successful defence of the empire in 363.

78 MCDONOUGH 2013, 601.
Indicative of this is the fact that in Shapur I's res gestae it was his military achievements, not his domestic ones, which were celebrated. This focus on the shah's military victories underline that it was for his martial prowess and success that Shapur wished to be remembered. Indeed, the underlying duty of a Persian ruler was the defence and expansion of their empire. ${ }^{79}$ Consequently, those shahs who did not display sufficient military prowess ran the risk of losing the support of the nobility, and even in some cases the throne itself, as happened to Balāš in $488 .^{80}$

The militaristic nature of Persian kingship meant that shahs were keen to be depicted as strong and masculine figures. Accordingly, Shapur I was keen to highlight the 'fame' that his military successes against the Roman Empire earned him, and to celebrate the 'bravery' he showed in these battles. ${ }^{81}$ In the same regard, rock reliefs such as those found at Bisapur, silverware such as the Paris Cameo and the equestrian statue of Khurso II all portrayed shahs in military garb or engaged in military activities. ${ }^{82}$ Hunting was also important in the militaristic image the shahs presented of themselves. As Wiesehöfer has stated, hunting had long been popular with the Persians due to its 'affinity with warfare', while Daryaee similarly remarks that to the Persians 'hunt[ing] mirrored warfare'. ${ }^{33}$ Thus, being seen as a strong hunter was akin to being perceived as a strong warrior in Persian culture. Importantly, Ammianus highlighted the importance hunting had to Persian rulers. During his service in Julian's 363 campaign the historian describes how the army passed through a royal estate that belonged to Shapur II which was decorated heavily with artwork that depicted the shah killing and hunting wild animals, and that wild beasts were kept for the Persian ruler's entertainment. ${ }^{84}$ Ammianus' information here is certainly corroborated by the popularity of silver bowls which depicted Shapur II in hunting scenes during his reign. ${ }^{85}$ Hunting scenes were important to the shahs, as symbols of their power and authority. ${ }^{86}$ Shapur II was certainly not the only shah to appreciate hunting and the symbolic importance of hunting; it was a major theme in Persian royal art and literature. Persian rock reliefs depict various shahs in the middle of hunts, such as that of Khusro II leading a boar and deer hunt at Taq-ī Bustan and that of Bahrām II at Sar Mashhad killing a lion. ${ }^{87}$

Ammianus Marcellinus was seemingly aware of the militaristic nature of Persian kingship. For example, he describes Shapur II's 'superhuman eagerness' to expand his realm through military conquest as well as his claim that he would reconquer Roman lands that had previously belonged to the Persian Empire. ${ }^{88}$ This description of Shapur, although likely intended to portray him as the aggressor against Rome, indicates how important military conquests were for

\footnotetext{
79 Thus, Hormizd IV explained to Roman envoys that he could not surrender Dara, as it was his duty as Shah to increase his realm not to decrease it (Men. fr 23.9.79-89).

80 For the case of Balāš see Joshua Stylites (18-19). WHITBY 1994, 247.

1 SKZ $\$ 27$.

82 GHIRSHMAN 1962, fig.195; fig.197; fig.235.

3 DARYAEE 2008a, 51; WIESEHÖFER 1996, 220.

$24.5 .2 ; 24.6 .3$

WIESEHÖFER 1996, 163

HARPER 2008, 72.

DARYAEE 2008a, 34, 52; WIESEHÖFER 1996, 161.

18.4.1; 17.5 .5
} 
the shahs and how eager they were to win such victories. ${ }^{89}$ Certainly, earlier in his narrative Ammianus also recounts the shah's demand that Constantius give up Rome's eastern provinces or face war. ${ }^{90}$ The indication here being that Persian shahs secured and expanded their borders through warfare, not diplomacy or negotiation, as indeed was the case in this period. ${ }^{91}$ The militaristic nature of Persian kingship is highlighted and reinforced again in Ammianus' information on Shapur's earlier campaign against the Chionitae on the eastern frontiers of his empire. ${ }^{92}$ Throughout his narrative Ammianus recounts all the major military activities of Shapur II and in the process creates the image of Persian kingship as one that was predominantly focused on military action.

That Ammianus' narrative makes clear the Persian's did not launch their attack against the Roman Empire in 359 until they had defeated the Chionitae on their northern frontier alludes to, or at least suggests, that since Shapur himself led both campaigns, a shah was expected to personally oversee major military campaigns. ${ }^{93}$ Ammianus' description of the Persian army during the preliminaries to the siege of Amida certainly reinforces the shahs' position as the supreme commander:

[the Persian army was] headed by the king in gleaming robes. On his left was Grumbates, king of the Chionitae, a man in middle life and of withered frame, but renowned for his great spirit and many glorious victories. On the king's right was the king of the Albani, Grumbates' equal in rank and honour, behind them came various highly placed generals, followed by a host of all ranks drawn from the flower of the neighbouring peoples and inured to hardship by long experience. ${ }^{94}$

This passage presents Shapur as the head of the Persian army, with all other notables and allied kings arranged either beside or behind him, in secondary positions. ${ }^{95}$ Ammianus reinforces this idea throughout the Res Gestae by recounting other examples were the shah alone acted as the supreme commander of the Persian army, personally leading troops on campaign and having the final decision on any and all tactical and strategic developments. ${ }^{96}$ In this regard, Ammianus was correct, royal leadership was a prerequisite of any major Persian campaign in the Sasanian period, and there are numerous examples of other shahs personally leading their troops on military campaigns which support this. ${ }^{97}$

89 BÖRM 2015, 269 certainly agrees that the shahs' legitimacy and right to rule was based fundamentally on their ability to gain military victories.

90 17.5.2.

91 This is also similar to Ardashir's earlier declaration to Severus Alexander that war, not diplomacy, would be used to settle their disputes (Herodian 6.2.2-5; Dio 80.4.1)

92 16.9.2.

93 WHITBY 1994, 234-40.

$94 \quad 18.6 .22$.

95 Ammianus' identification of Shapur in this passage has been the subject of some debate, MATTHEWS 1989, 62. Although given the nature of Persian kingship and military there is arguably more scope to believe Ammianus was correct, and that Shapur was personally leading the army.

$96 \quad 19.1 .1,19.1 .5-7$

97 For example, there is evidence that Ardashir (Dio 80.4.1), Shapur I (SKZ $\$ 11,4-3$ ), Peroz (Proc. BP. 1.3.23-4, 1.4.25-28; Lazar P'arpets'I, 214-15) and Khusro I (Menander 18.6; John of Ephesus HE 6.9), among others, personally took charge of the Persian army on campaigns beyond the empire's borders. Whitby (1994) 234-40 also supports that this was indeed a requirement of Persian military campaigns. One notable exception to this took place in the
Ammianus' comment that the shahs were 'never obliged to fight in person' and that Shapur II's personal involvement in the fighting at Amida was 'unprecedented' makes it clear that he believed Persian rulers were not expected to endanger themselves in direct combat with enemy troops. ${ }^{98}$ Although this is more debatable and harder to validate than other information given by the historian there is nevertheless some evidence to support Ammianus' claim. First, when one compares Shapur II's actions outside the walls of Amida, where he is said to have 'rushed forward into the thick of the fray like a common soldier', with those of his counterparts in other sieges and battles with Roman troops it does appear unusual. For example, at the later siege of Amida in 502/3 Kavād was said to have spurred his troops on by shouting encouragement with his sword drawn at the bottom of a ladder, without actually engaging the Roman defenders. ${ }^{99}$ Similarly, during the siege of Antioch in 540 Khusro I encouraged his soldiers to press the attack at a weak-point in the city's defences but did not lead the attack himself. ${ }^{100}$ From such comparisons it can be argued that the norm was for indirect involvement, encouraging or berating the troops, rather than fighting shoulder-to-shoulder with them. Secondly, when not encouraging their troops at the heart of the battle, there was a tradition for shahs to position themselves in a nearby location that permitted them a strategic view of the battle. We are informed that this was the case during the sieges of Petra in 541, Edessa in 544 and Bara in 573, where Khusro stationed himself on a hill overlooking the city. ${ }^{101}$ This tradition corroborates Ammianus' idea that shahs had the final say on all tactical and strategic decisions, as to make such decisions they would logically need to gauge the progress of a battle from a good vantage point. It is for these reasons that Whitby has suggested Ammianus was probably correct in his assessment that it was rare, if not unprecedented, for shahs to become personally involved in direct combat with enemy troops. ${ }^{102}$

\section{AMMIANUS ON THE PERSIAN NOBILITY}

As with any ancient state, the nobility played an important role in the political composition and constitution of the Persian Empire. Pourshariati has recently argued that the Persian Empire was not as centralised as previously thought, but was controlled through a combination of direct and indirect rule. ${ }^{103}$ In this regard, the powerful noble families and clans that made up the upper echelons of Persian society often ruled different regions of the empire virtually independently. The Persian nobility itself was split into different groups based upon a hierarchy of power and influence. These different noble groups included the Šahrdārān, local dynasts and sons of the ruling shah who

short-lived Roman-Persian conflict of 421 when Mihr Narsēh led the Persian army against the Romans. However, there were some unique mitigating circumstances that explain this. First, Mihr Narsēh was appointed as grand vizier (vuzurg framādār) to act as regent for Bahrām V. Secondly, Mihr Narsēh, was only appointed as regent while Bahrām himself was on a far more important military campaign on the empire's eastern frontier.

98 19.7.6. Procopius (BP. 2.17.9) also seemingly supports this statement.

Zach. HE 7.3-4.

100 Proc. BP. 1.7.28

101 Proc. BP. 2.17.9, 27.11; John of Ephesus HE 6.5.

$1021994,240$.

1032008 
were entrusted to govern important parts of the empire, the Wispuhrān, members of the royal clan who did not belong to the shahs immediate family, the Wuzurgān, the great noble clans of the east, such as the Karin, Suren, Waraz and Mihran, who retained considerable independence in their traditional homelands, and the Āzādān, the lesser of all the nobles. ${ }^{104}$ Shahs could not rule without the consent and cooperation of the nobility; laws could not be issued, armies could not be mustered or new taxes raised without the agreement from the nobility. ${ }^{105}$ This made them a powerful and influential force within the empire. Indeed, if a ruling shah angered the nobles sufficiently they could cause enough trouble that the ruler's hold on the throne could became untenable. ${ }^{106}$ The importance of the Persian nobility is reflected in how heavily they feature in Ammianus Marcellinus' narrative. Indeed, it is hardly surprising that as a member of the Roman elite Ammianus dedicated a considerable amount of his work to providing information about his Persian counterparts.

One of the first examples of Ammianus' knowledge of the role the nobility played in the running of the Persian Empire comes from his description of Shapur II's preparations for his attack against the Roman Empire in 359. According to Ammianus the nobility played a key role in these preparation. He informs us of the practice of 'banquets [organised by the shahs] at which, like the ancient Greeks, the Persians are in the habit of discussing military and other serious matters'. ${ }^{107}$ Although Ammianus, quite frustratingly, does not provide further illumination on the composition of these banquets, which will cautiously be called councils here, or on what the 'other serious matters' are that were discussed, this is nevertheless an important observation. His comment that that these banquets resembled those of the 'ancient Greeks' implies that they followed similar lines to earlier Greek examples with which his Roman audience were likely more familiar. If so this implies that membership of these council-banquets depended on the personal choice of the shahs, as their Greek predecessors were based on personal friendship and acquaintances. ${ }^{108}$ Likewise, in this way it can be suggested that these banquets were similar to earlier Hellenistic examples that were composed on the principle of the 'King and his friends (Philoi)'. That the personal choice of, and relationship with, the shah was an integral condition to being invited to these banquet-councils can be collaborated by the fact that the arrangement of noble's names and clans in the rock reliefs of the early shahs were based partly on the personal choice of the shah. For example, discussing the res gestae divi Saporis, Wiesehöfer has stated that 'the list [of nobles] is evidence both for the dignitaries personal relationship to the king and for [Shapur's] appointment of people to office on the basis of decisions of character and/ or talent'. ${ }^{109}$ Therefore, Ammianus' comparison of Persian

104 Each of these noble groups are mention by Shapur I in his inscription at Hajjiabad, during his description of an archery competition at which he triumphed (ك̌H 1-6). RUBIN 2000, 652 and WIESEHÖFER 1996, 171-5 have also identified them as the most important noble groups in the Persian Empire.

105 BROSIUS 2006, 151-179.

106 John of Antioch fr. 178; FHG 4: 165; The Letter of Tansar; NPi. BROSIUS 2006, 151 .

$107 \quad 18.5 .8$.

108 BÖRM 2007, 136 also advocates this theory.

$1092007,72$. banquets to their earlier Greek counterparts could suggest he was aware that personal choice and relationships were just an important a consideration in the hierarchy of the Persian nobility as anything else.

Although Ammianus does not elaborate on what 'other serious matters' the nobility discussed with their shah this statement does nevertheless indicate he was aware that the Persian nobility played an important role in multiple aspects of the running of the state. Indeed, this is later made clear by Ammianus' claim that nobles of sufficient rank were permitted 'to offer advice and bring forward [their] views in discussions of affairs of the state'. ${ }^{110}$ Despite the fact that he does not offer more information on the 'other serious matters' that the nobles were free to discuss it is nevertheless true that other matters were open for noble input and advice. For instance, judicial councils made up of nobles could decide the fate of shahs, such as the council of 469 that debated the 'crimes' of Kavād. ${ }^{111}$ Nobles and councils of nobles were also integralin thelegitimisation and proclamation of newshahs. ${ }^{112}$ Indeed, Procopius writes that 'no one ought to assume the royal power on his own initiative but by the vote of the Persian notables. ${ }^{113}$ Therefore, Ammianus' recognition that the nobility played an important role in the decision-making processes of the Persian Empire shows good knowledge of its political apparatus. ${ }^{114}$ Indeed, Shah Narsēh himself confirms Ammianus' information on the importance of nobles and noble councils, as his Paikuli inscription identifies the 'king's council' as playing an important role in his ascension to the throne and overall legitimacy. ${ }^{115}$

As a soldier himself it is no surprise that Ammianus Marcellinus had a particular interest in the role the Persian nobility played in the army. His personal involvement in the two major Roman-Persian conflicts during his lifetime helps to explain Ammianus' understanding of the martial responsibilities of the Persian nobility. For example, he was aware that the highest military office in the Persian army, behind the shah of course, was that of the Surena. ${ }^{116}$ Elsewhere, by relating the activities of Persian regimental leaders such as Tamsapor, Nohodares and Merena during conflicts with Rome, he indicates that even lesser offices in the army were reserved exclusively for the nobility, and that these positions were not merely ceremonial but came with real responsibilities. ${ }^{117}$ At the battle of Amida in 359 Ammianus was keen to describe how the Persian nobility 110 18.5.6.

11 Proc. BP. 1.5. Another example of a judicial council in Procopius' work can be found at 1.11.31-33. Börm (2010) 184 also highlights the potential for noble councils in removing a shah.

112 Proc. BP. 1.11.31-33; BÖRM 2007, 113; 2008b, 433; WIESEHÖFER 1996, 169-171. BROSIUS 2006, 160 also recognises the role the nobility frequently played in the selection of the shah.

113 Proc. BP. 1.21.20. According to BÖRM's 2007, 113 reading of Procopius, choice of election by the nobility was one of the fundamental perquisites of a shah's legitimacy.

114 Their importance is also agreed upon by modern historians, such as BROSIUS 2006, 168 who states that the Persian nobility acted as advisors to the shahs as members of the 'King's Council'.

115 NPi $₫ 68$. Likewise, that Narsēh criticised the 'sham consultation' that took place in support of his rival Bahrām III, also shows that Bahrām tried to utilise nobles to legitimise his claim to the throne and, therefore, reinforces the importance of nobles and councils in the running of the Persian Empire $(\$ 73 ; 75)$.

116 24.2.4.

$117 \quad 18.8 .3,25.1 .6$ 
were eager to personally join in the fighting on the city's battlements in order to prove their bravery and skill. ${ }^{118}$ Ammianus was evidently aware that the nobles played a fundamentally important role in the military strength and success of the Persian Empire. ${ }^{119}$ Certainly, his presentation of the Persian nobility's direct involvement in warfare agrees with nobles' own perception of themselves as arteshtaran, arteshtarih, a warrior aristocracy. ${ }^{120}$ The militaristic nature and capabilities of the Persian nobility is further evident in the fact that the shahs were reliant on them, especially the Wuzurgān to provide the heavily armoured cavalry which formed the core of the Sasanian armies. ${ }^{121}$

Ammianus' work highlights that the wearing of certain jewellery was used to designate status and rank among the Persian nobility. He informs us that the wearing of a tiara or diadem entitled the wearer to "be placed at the royal table, and to offer advice and bring forward his views in discussions of affairs of state'. ${ }^{122}$ This knowledge is also corroborated by the sixth century historian Procopius, who relates that certain types of jewellery, which designated rank and position, could only be granted by the Shahs. ${ }^{123}$ Perhaps even more importantly, the Letter of Tansar also acknowledges the role jewellery played in the representation of the hierarchy of power. ${ }^{124}$ Taken together, Ammianus' knowledge of the implications of specific jewellery-wearing and the nobility's clearly defined roles in the military suggests that, although he does not make it explicitly clear, as the later Procopius does to a greater degree, he had some awareness of the heavily structured, hierarchical and hereditary nature of the Persian nobility. ${ }^{125}$ Certainly, the existence of a hierarchy among the nobility that was designated by the wearing of specific jewellery is acknowledged by modern historians, who note that different colours and emblems distinguished between the different ranks of nobility. ${ }^{126}$

Ammianus' focus on the nobility throughout his narrative and his accounts of their varied activities within the running of the Persian state underlines his awareness that they played a central role in the empire.

\section{AMMIANUS ON SASANIAN PERSIAN IDEOLOGY}

That the rule of my ancestors once extended to the Strymon and the borders of Macedonia is a fact to which even your own ancient records bear witness, and it is right

119 The importance of the nobility in the success and strength of the Persian army is also recognised by PAYNE 2016, 258 who says that the troubled north and northeastern frontiers became a deathtrap for the nobility, who served as the army's leaders and heavy cavalry, in the fifth century.

120 MCDONOUGH 2013, 604.

121 MCDONOUGH 2011, 299; POURSHARIATI 2008, 56. On the cavalry forming the core of Sasanian armies see GREATREX 1998, 53-54.

122 18.5.8.

123 Proc. BP. 1.17.27. Other sources Roman which attest the importance of certain jewellery amongst the Persian nobility include Agathias (3.28.5).

12444.

125 Procopius' awareness of the structure and hereditary nature of the Persian nobility is evident in different passages (BP. 1.6.13-14; 1.9.4, 1.23.14). On how the nobility and Parthian clans maintained their position and survival throughout multiple generations see PAYNE 2016.

126 BROSIUS 2006, 168. WIESEÖFER 1996, 172 states that 'Belts studded with gems and earrings played a part in symbolising the different ranks and statuses within the Persian nobility and also suggests that 'a certain way of dressing' may played a similar role.
}

that I should demand this territory. ${ }^{127}$

As shown from this extract, taken from the failed negotiations between Shapur II and Constantius in 358, Ammianus Marcellinus propagated a certain perception of Persian imperial ideology in the Res Gestae. Namely, that the Sasanian Persians viewed themselves as the heirs to the Achaemenid Empire. The veracity of Sasanian Persian claims to Achaemenid heritage has been keenly debated by scholars. ${ }^{128}$ Those who disagree with it claim such Persian heritage-claims were strictly a Roman invention, arguing that it is more prevalent in Roman sources than their Persian counterparts, resulting from the Romans' own need to rationalise and understand Persian aggression through Greco-Roman traditions and historic view of the world; that this was a tradition the Sasanian Persians knew, or cared, little about. ${ }^{129}$ However, there is convincing evidence to suggest that Achaemenid heritage did play a role in Sasanian ideology, especially in the early stages of their rule. ${ }^{130}$ For example, both al-Tabarī and the Letter of Tansar reveal that Persian knowledge of the Achaemenid past formed an important part of their early ideology, imperial policy and worldview. ${ }^{131}$ Likewise, it is well attested that important Sasanian Persian monuments were located in areas that were particularly poignant in Achaemenid memory and history. Most famously, Shapur I's res gestae divi Saporis was carved into the Ka'ba-i Zardušt, a fire sanctuary built during the reign of the Achaemenid king Darius I. ${ }^{132}$ That Shapur I's monument was specifically located at such a historically meaningful site seems unlikely to have been a mere accident or coincidence. It is more likely this site was chosen for s specific purpose: to justify the Sasanian shahs right to rule, by linking themselves with, and promoting

\footnotetext{
27 17.5.5.

128 For a conclusive analysis of this important question see SHAYEGAN 2011. 129 Both Herodian (6.2.1-2) and Cassius Dio (80.4.1) narrate similar arguments for Persian aggression. On the influence of Greco-Roman historical knowledge affecting Rome's understanding and perception of the Persians see BLOCKLEY 1992, 114. Scholars who claim this was a Roman invention include; KETTENHOFEN 1984, 183-4; POTTER 1990, 370-80; 2006, 222-4; HUYSE 2002. In contrast, BLOCKLEY 1992, 104 argues that although this Achaemenid heritage was unlikely to be merely a Roman invention, it does not indicate a Persian will to world domination in the same way that later Christian universalism did for the Romans.

130 Scholars who argue for the importance of Achaemenid heritage to the Sasanians themselves include: FOWDEN 1993, 22; DIGNAS/WINTER 2007, 55; DARYAEE 2006, 493; SHAHBAZI 2001, 61; WALKER 2007, 795. POURSHARIATI 2008, 33 indicates that such emulation or claim to Achaemenid heritage would not have been beyond the Persians, who always tried to 'connect their humble origins to remote antiquity'.

${ }^{131}$ Letter of Tansar 42; Tabarī 814. Although the Letter of Tansar was supposedly written during the reign of Ardashir I, as a royal dispatch to a loyal governor, it is more likely that it was created during the reign of Khusro I, 531-579: WHITBY 1994, 235; FOWDEN 1993, 29. Nevertheless, whichever shah commissioned it, the significance of Achaemenid heritage to Sasanian ideology, especially towards the Roman Empire, is revealed to be highly important by this letter. Similarly, although Tabarī, a Muslim writer from the tenth century A.D, was far removed from the events described here he is generally thought to be a reliable and accurate source, CONRAD 1993. Indeed, it is believed that Tabari incorporated the classical traditions of the X'adāyNāmag (Book of Kings), an official historiography sanctioned by the shahs themselves, in his own work and therefore it could be suggested that Tabari would have, intentionally or unintentionally, presented important ideals, such as Achaemenid heritage, to his audience that the shahs had wished to present to their audience when patronising the Book of Kings POURSHARIATI 2008, 9-13; YARSHATER 1983, 360-363. 132 DINGAS/WINTER 2007, 57.
} 
themselves as the heirs to, the Achaemenids. Furthermore, although direct reference to Achaemenid heritage may be absent from Sasanian royal proclamations, Achaemenid past was nevertheless an intrinsic part of Sasanian culture. For example, Iranian literary and oral tradition ensured that Alexander the Great was long remembered as the destroyer of the Achaemenid Empire. ${ }^{133}$

In the debate on Sasanian ideology it is important to remember Shayegan's comment that the Persians' political ideology underwent considerable changes throughout the empire's history, that it was affected by, and responded to, political circumstances and conditions. ${ }^{134}$ As such, it is important to view Sasanian ideology in the context of the political and military threats they faced at different points in their history, and to understand that a state's ideology inherently silhouettes itself against its neighbours and the outside world, as well as its actions against these neighbours. ${ }^{135}$ Thus, in the fourth century, when Ammianus was writing, the fact that Persia's military focus was predominantly focused on Rome had a major impact on their ideology and ideological outlook. ${ }^{136}$ By promoting Achaemenid heritage the Sasanian Persians were inserting themselves into the ancient battle between east and west in order to justify their actions towards the Roman Empire. For this same reason, the argument that Kayānid heritage played a more formative role in Sasanian Persian ideology than Achaemenid memory at this stage of their history must be countered. ${ }^{137}$ It was not until the fifth century, when Persia's military focus increasingly shifted to the Hephthalite threat on their north-eastern frontier, that an analogous shift occurred in Persian imperial ideology in which Kayānid memory gained prominence. ${ }^{138}$ The mythical Kayānids were said to have fought many battles against northern enemies, the Turanian, in the protection of the Persian heartlands. Therefore, a shift from Achaemenid to Kayānid ideological heritage in the fifth century allowed the Sasanians to once again fit themselves in another ancient battle between Iran and its enemies in the justification of their foreign policy. Thus, due to the geopolitical conditions facing the Persian Empire in the fourth century Achaemenid heritage played an important and immediate role in Sasanian Persian ideology. For these reasons, Ammianus' information on Persian ideology in this period should be viewed with credibility, and not simply as literary invention. This once more reiterates the need to judge Ammianus' knowledge of the Persians only by the conditions that existed in the period he himself was writing.

\footnotetext{
133 YARSHATER 1983, 377-91, 472-72; BÖRM 2008, 426.

134 SHAYEGAN 2013, 805-806. This is also supported by DARYAEE's 2008b, 60 reminder that Persian kingship was not static or unchanging.

135 CORBEY/LEERSSEN 1991; MILES 1999, 10; ANDOA 2000, 20; BRUNT $1978,159$.

136 Indeed, CANEPA 2009, 51 even suggests that the Sasanian use of Achaemenid heritage was done in direct response to the traditional tradition of imitatio Alexandri amongst the Roman emperors.

137 For the argument that Kayānid memory was the defining aspect of Sasanian Persian ideology see: ROAD 1998.

138 SHAYEGAN 2013, 807, and SHAHBAZI 2001 also agree with this point. DARYAEE 1995, 136 points out that 'by Kavād's reign (488-531) Keyanid names and legends had become a main component of Sasanid ideology'. For more on the nature of the Persian military shift to the north-eastern frontier see p.26.
}

\section{AMMIANUS ON SASANIAN FRONTIERS AND TERRITORY}

Due to a large part of Ammianus Marcellinus' narrative focusing on military campaigns and conflicts between the Roman and Persian Empires his work contains valuable information about Persian frontiers and some aspects of its internal territorial composition. Importantly in this regard, Ammianus' work shows that the Persian Empire was just as heavily defended as the Roman Empire on the contested frontier in Mesopotamia. This is evident in his narration of Julian's invasion of the Persian Empire in 363, in which he describes the emperor and his troops besieging and capturing fortified cities and military installations such as Maozamalcha and Pirisabora, while even islands within the Euphrates which had been fortified by the Persians had to be overcome. ${ }^{139}$ Ammianus' assessment of the Persian frontier in Mesopotamia certainly agrees with other evidence of the strong defences of the Persian Empire. For example, we know that the Persians made substantial efforts to defend all the major routes to the capital of Ctesiphon, through the construction of military installations as the Nahrmalcha (royal canal), which stretched from the Tigris to Ctesiphon, and the heavily fortified city of Veh-Ardashir. ${ }^{140}$ Likewise, Ammianus' comment about fortified islands in the Euphrates is supported by archaeological evidence which has uncovered fortifications on river-islands such as Anatha and Bijan. ${ }^{141}$ In further support of Ammianus' narrative which suggest that the Persian Empire was defended by a variety of different fortifications both on its frontiers and along vital internal transport routes, it has been stated that, invaders 'faced a variety of walled cities, fortresses and linear defences constructed by local, aristocratic and royal initiative.. ${ }^{142}$

Alongside Ammianus' information on Persia's western fortifications the Res Gestae is also a useful source of information in establishing a wider picture of the geopolitical conditions the Persians faced during the latter stages of the fourth century. Before Shapur II's attack on the Roman Empire the historian informs us that the shah was 'detained at the other end of his realm' by the Chionitae 'on his furthest borders', in a campaign that was cost his army 'much bloodshed'. ${ }^{143}$ Ammianus was aware that the Persians faced threats other than Rome elsewhere in the empire, and, importantly, he had a clear idea of who at least one of these threats were: the Chionitae. ${ }^{144}$ This can arguably be pushed further by suggesting that, since Ammianus notes Shapur did not turn his military attention to Rome until the Chionitae threat on the northern frontier had been secured, he creates the impression that the northern frontier and the enemies the Persians faced there were just as much a threat, if not more so, as the Romans. ${ }^{145}$ Such an idea is certainly true, despite the fact Roman historians obviously tended to focus on their own wars with the Persians, as Ammianus largely

\footnotetext{
3924.

140 MATTHEWS 1989, 145-55.

${ }_{141}$ For Anatha see EDWELL 2008, 72, 82. For Bijan see GAWLIKOWSKI 1985. 142 MCDONOUGH 2013, 609. For more on the defences of the Persian Empire see KLEISS 2001.

$14315.13 .4 ; 16.9 .2,17.5 .1$

144 16.9.2. For a more detailed discussion of the earlier Persian conflicts with the Chionitae see CHEGINI/NIKITIN 1996.

145 17.5.1.
} 
does himself, and that in the early period of their rule the Sasanian Persians were able to operate in relatively benign geopolitical circumstances. ${ }^{146}$ Nevertheless, during the later fourth century when Ammianus was writing and even more so in the fifth century, threats from the Chionitae and other Hunnic groups, such as the Kidarites and Hepthtalites, resulted in a shifting of Persian military priorities that increasingly focused on their northern frontier. ${ }^{147}$ As such, Ammianus' recognition that the Persians also campaigned heavily and for long-periods on their northern frontier and that this area was just as important for their security as Mesopotamia should be seen as further evidence of his knowledge of the Persian Empire.

\section{AMMIANUS ON ROMAN-PERSIAN INTERAC- TIONS AND CULTURAL PERMEABILITY}

Despite Ammianus Marcellinus' usefulness in providing information about the frontier defences of the Persian Empire the historian was also aware that the RomanPersian frontier was not an iron-curtain which separated the Roman and Persian populations and kept them completely apart. Rather, the Res Gestae highlights the prevalence of cross-border travel and cultural permeability between the two empires.

Ammianus makes it clear that the frontier region between the Roman and Persian Empires in Mesopotamia was an area that was populated by ordinary people and civilian settlements, not just soldiers and military installations. For example, while narrating the career of Antoninus and his eventual defection to Persia, we are informed that the merchant 'bought a cheap in property in Hiaspis immediately bordering the Tigris'. ${ }^{148}$ Furthermore, he informs us that prior to its besiegement Amida had become 'swollen by crowds of country folk' who had travelled to the city for a festival before becoming trapped by the invading Persian forces. ${ }^{149}$ This statement clearly implies that it was not just the large cities that were heavily populated, but that there was also a substantial rural population near the imperial frontier. That Ammianus recorded the many cities and populated islands that he marched past in Julian's campaign and that Persian territory near the frontier was 'copiously irrigated' infers the same conditions existed on the Persian

\footnotetext{
146 On the benign geopolitical circumstances of the early Sasanian Persian Empire see HOWARD-JOHNSTON 2010, 41.

147 DARYAEE 2008a, 23 notes a distinct military shift to the east during the early reign of Bahrām V (420-439), which was arguably confirmed when his successor, Yazdgard II (438-457), who suffered numerous defeats to the Hephthalites throughout his reign, soon found it necessary to station himself permanently in Khurasan after 442, so that he could focus on defending his vulnerable north-eastern frontier against their incursions: DARYAEE 2008a, 23. This shift towards the northern frontier in the fifth century was confirmed by the construction of the Gorgan Wall, which stretched for $195 \mathrm{~km}$ from the Caspian Sea to the Turkmen Steppe and provided a continuous barrier between the Persian Empire and the Hephthalites across the north-eastern frontier. For more detailed discussions on the Gorgan Wall see:

NOKANDEH et alii 2006, 121 and SAUER/REKAVANDI/WILKINSON/ NOKANDEH 2013. The Gorgan Wall is also known as the Red Snake and the Barrier of Peroz. Certainly, picking up from where Ammianus seemingly left of the sixth century Procopius' work, The Persian Wars, includes substantial information on the Persians wars on their northern frontier against the Hephthalites (1.3.1-6, 1.3.23-4, 1.4.25-28).

148 18.5.2.

149 18.8.13
}

side of the border. ${ }^{150}$ Certainly, the fact that the early shahs undertook large urbanisation and irrigation projects in order to improve the infrastructure of their empire supports the picture of heavily populated Persian frontier regions. ${ }^{151}$ The Persians would not have built more cities and expanded agricultural land if they did not have the people to populate these cities or the need to feed a larger mass of people.

Ammianus' statement that frontier guards were needed to keep the two populations apart can be argued to show that the Roman and Persian frontier populations lived in relatively close proximity to one another. ${ }^{152}$ That there was such close proximity between the civilian populations of both empires ensured the conditions for cross-border travel and interaction existed. ${ }^{153}$ In this regard, Ammianus' description of the frontier zone between the Roman and Persian Empires is relatable to, and arguably corroborated by, Procopius who, although exaggerating, states that ' $[\mathrm{t}]$ here was no marked frontier' between the populaces of the Roman and Persian Empires and that they 'intermarried and had joint markets'. ${ }^{154}$ Such close proximity and cross-border travel was certainly likely in the densely populated Fertile Crescent, which was one of the most vibrant and flourishing regions of both empires and which, although politically divided, was never culturally divided into strictly Roman or Persian groups. ${ }^{155}$

Although Ammianus does not explicitly state that cross-border interactions between the Romans and Persians were common, as Procopius does, he does nevertheless provide evidence that it did take place. The historian displays this knowledge with his inclusion of notable figures such as Antoninus, Craugasius, Jovinian and Hormzid who appear at different points in his work. These four men, two Roman and two Persian, each crossed the imperial border at different times, for different reasons and spent considerable periods of their lives in the other empire. Ammianus' inclusion of both Roman and Persian individuals is important as it shows he was aware that cross-border travel took place in both directions. Perhaps the most famous example of these is the aforementioned Roman merchant, Antoninus, who was forced to flee into Persia after he found himself on the wrong side of powerful enemies. ${ }^{156}$ After Antoninus crossed the border he promptly began selling sensitive military

\footnotetext{
$50 \quad$ 24.3.10.

51 HOWARD-JOHNSTON 2008, 125-7; WIESEHÖFER 1996, 192.

152 18.5.2. Ammianus information on the existence of frontier guards is
} supported by Jerome in his Life of Malchus (23.54), where he describes the problems faced by Malchus, who was stopped from crossing the frontier due 'the Roman soldiers on guard'

153 In seeking to understand the mechanics behind cross-border travel and the movement of people from one region to another the social gravity model highlights both high populations and a short distance between these two populations as key elements, LOWE/MORYADES 1975, 276. LEE 1993, 150 has previously utilised the social gravity model to analyse cross-frontier travel between the Roman and Persian Empires.

154 De. Aed. 3.3.9-10.

155 MITCHELL 2007 330, 342. BROWN 1969, 93 also highlights this from a Roman imperial perspective; 'Diocletian had made the mistake, pardonable in a Roman if not in a modern historian of Near East culture, of treating Persian-controlled Mesopotamia tout court as "Persia." FOWDEN 1993, 17 furthers the importance of the culturally connected frontier region and people, especially Mesopotamia, which he states was a cultural highway and that 'Though far apart, then, the Mediterranean and Iran are not unrelated; they are equally implicated in Syria-Mesopotamia.'

18.5. 
information to the Persians in order to ingratiate himself to his new hosts. ${ }^{157}$ The Persian prince Hormizd, brother of Shapur II and rival claimant to the Persian throne, likewise crossed the border in order to seek protection against his enemies in his native homeland. ${ }^{158}$ The case of Jovinian was slightly different than Antoninus and Hormizd in in that he crossed the frontier in an official capacity: as a diplomatic hostage. ${ }^{159}$ Whereas these first three examples have been largely accepted as genuine, the case of Craugasius has been the source of some dispute between scholars. ${ }^{160}$ Some historians have suggested that the Craugasius tale, in which the nobleman's love of his wife is the primary motivating factor in his move into the Persian Empire, is simply a romantic tale with little wider context or consequence on Ammianus' wider narrative. ${ }^{161}$ However, as Kaldellis has pointed out in his study of Procopius, such tall-tales, if that is what the Craugasius incident was, served a purpose in the later historian's work by providing a context in which the character of states and individuals could be judged. ${ }^{162}$ Thus, if seen in this context, it could be suggested that whether a man named Craugasius did actually cross the border or not is not overwhelmingly important for this particular study, as, either way, it shows that Ammianus was aware of the possibility of cross-border travel between the Roman and Persian Empires. Thus, the examples of these three four men reveal that Ammianus was aware that despite the best efforts of the two empires cross-border travel was possible and relatively common.

In the same regard, Ammianus informs us that information could be spread from one empire to the other by 'rumours'. ${ }^{163}$ In the ancient world knowledge, in the form of rumours in this case, could only be passed from one region to another through the movement of people. ${ }^{164}$ Therefore, if rumours moved between the Roman and Persian Empires, as Ammianus suggests they did, it necessitated that people also moved between the two empires. Ammianus' information in this regard has certainly been corroborated by recent scholarship which has highlighted the prevalence of cross-border travel between the two empires. ${ }^{165}$ Procopius 157 Ibid.

158 Homizd appears at different times throughout the narrative; accompanying Constantius to Rome $(16.10 .16)$ and at certain points in Julian's invasion of the Persian Empire $(24.1,2,5,8)$. Unlike the other examples in Ammianus' work we are not informed precisely when or how Hormizd crossed the frontier, although Ammianus comment that he had previously mentioned the Persian prince (16.10.16) may suggest this information was to be found in the lost earlier books of the Res Gestae.

159 Jovinian is introduced during Ammianus' own intelligence gathering mission to the Persian province of Corduene, where Jovinian was the governing Satrap (18.6). Although given LEE's 1991 argument that hostages in Roman-Persian diplomacy in general were only exchanged as short-term guarantees while negotiations were being conducting or on the initiative of local commanders, the nature of what sort of hostage Jovinian was and how long he was detained in Roman territory is left ambiguous.

160 Craugasius' defection across the Persian frontier can be found at 19.9.

161 THOMPSON 1947, 2; MATTHEWS 1989, 347.

$1622004,62-65$.

$163 \quad 18.4 .2 ; 18.6 .2$

164 LEE 1993, 149; FOWDEN 1993, 12.

165 LEE 1993 for instance, has convincingly argued that the movement of both people and information across the imperial frontier was not only possible but, in certain periods, quite prevalent. CANEPA 2009, 1 likewise shows that the characteristics of the Roman-Persian relationship enable these two hostile systems of sacred universal sovereignty not only to coexist, but to foster exchange and communication even in the face of an undying rivalry'. similarly vindicates this information in his own work through the justification, 'the Persians say', which implies his information came directly from the mouths of Persians themselves. ${ }^{166}$ Certainly, just as Antoninus, Craugasius, Hormizd and Jovinian all crossed the frontier for different reasons many different groups and individuals, such as Christians, merchants and diplomats, all travelled between the two empires. ${ }^{167}$

Moreover, Antoninus' and Craugasius' acceptance into the Persian court and their ability to integrate themselves into Persian society with apparent ease underlines the cultural permeability and compatibility that existed between the Roman and Persian Empires, at the elite level at least. Antoninus' ability to be understood when speaking in the councils of the Persian shah and his advisors, and this was also presumably the case for Hormzid in the Roman court, highlights that linguistic understanding was possible between Roman and Persian elites. Likewise, that Ammianus himself was friendly with Jovinian even before crossing into his satrapy suggests that ties of friendship existed across the frontier. ${ }^{168}$ Ammianus' inclusion of the lives and careers of these three men demonstrates he was aware that there was no major cultural block or incompatibility that prevented Roman and Persian elites from becoming important individuals in the other empire and interacting with one another. ${ }^{169}$ Indeed, the examples of Antoninus and Craugasius have similarly been highlighted elsewhere as evidence of the symmetrical cultural adaptability between Roman and Persian elites, ${ }^{170}$ while Jovinian's love of Roman culture shows it was not innately abhorrent to all Persians. ${ }^{171}$

Ammianus provides a direct example of the cultural exchange and adaptability that existed between the Romans and Persians with his retelling of the Roman capture of a 'royal lodge built in the Roman style' near Seleucia in $363 .{ }^{172}$ During their invasions and military incursions into Roman territory successive shahs forcibly transported many Roman captives into the Persian Empire, something that Ammianus himself was aware of, ${ }^{173}$ to exploit their expertise and knowledge in construction projects and in order to improve the empire's infrastructure. ${ }^{174}$ Most famously, we know that many Roman captives, maybe even the emperor Valerian himself, worked on the Sostar Dam. ${ }^{175}$ Therefore, it should come as no surprise that many of these buildings would feature Roman stylistic and decorative imitations. Certainly, 166 BP. 1.4.17, 18, 22.

167 See LEE 1993 and MORLEY 2016 for more information on this.

168 18.6.19.

169 Certainly, that such a cultural adaptability, exchange and interaction between the elites of the two empires existed has recently been convincingly argued for by CANEPA 2010.

170 DRIJVERS 2011b, 29.

171 18.6.17-20. That Khusro I was said to be very interested in Roman culture and had Greek and Roman literature translated into Persian (Agath. 2.28.1-2) can also be used to show that there was Persian interest in Roman culture and that Ammianus' comment on Jovinian's love of Roman customs and traditions was not merely an attempt to show the superiority of Roman culture.

172 24.5.1.

$173 \quad 19.6 .1-2$

174 Certainly Shapur I himself was keen to boast that he had deported substantial numbers of Roman captives into different provinces of his empire $(S K Z \$ 30)$. Such deportations are also confirmed by the Chronicle of Se'ert (PO 4. 220-1) and Tabarī (827-8). For discussion on this SIMSPON 2000, 3766; SCHWAIGERT 1989, 19-33.

175 Tabarī 827-8; GHIRSHMAN 1962, 137 fig. 174. 
it has been noted that the royal palace at Bisaphur included many Greco-Roman influences such as Greek key patterns, leaf-scrolls, dentils and floor mosaics. ${ }^{176}$ The city of Bisaphur itself was based on a Roman military camp and was populated largely by captured Roman soldiers. ${ }^{177}$ Likewise, both Procopius and Tabarī later attested that Khurso constructed a city that was built in the exact likeness of Roman Antioch. ${ }^{178}$ Therefore, Ammianus' information on this Persian imitation of Roman architecture in Shapur II's royal lodge should be regarded with some credence. This fact has certainly been recognised in modern scholarship, as evident in Canepa's discussion of architecture during the reign of Khusro II, which he states featured prevalent juxtapositions of Roman and Persian designs and decorations. ${ }^{179}$.

Throughout his narrative Ammianus presents a nuanced version of the cultural relationship between the Romans and Persians than the idea of the strange and feared alter orbis that was propagated by other contemporary Romans. He was seemingly aware of the cultural similarities between the two empires and the potential for cultural exchange. Seen in this light the Res Gestae is therefore an important source in showing that there was no 'iron curtain' relationship of unbridled hatred and separation between the peoples and cultures of the two empires, but rather that there were varying degrees of connectivity and interaction.

\section{CONCLUSION}

Throughout his narrative Ammianus includes important and accurate information on the Persians and their empire which confirms the Res Gestae as a useful and knowledgeable source on the fourth-century Persian Empire. By recalling and exploiting his own experiences, as well as information gained elsewhere, Ammianus provides his audience with accurate and often highly nuanced information on Persian kingship, nobility, ideology, frontiers, geography, and the cultural permeability and adaptability of the Roman and Persian Empires. The historian evidently had good knowledge of the Persians and their way of life that, although perhaps not immediately obvious, especially when focusing on the Persian digression, can be found throughout his work. In the digression Ammianus only included his own experiences and first-hand accounts relatively sparingly and in understated terms, in order to not give them too much weight over more traditional aspects of Greco-Roman historiography and ethnography on Persia and the Persians. Thus, as Drijvers has noted, in the Persian digression Ammianus' 'own observation did not play a role of any importance; Ammianus seeks rather to connect with the prevailing historiographical and literary conventions'. ${ }^{180}$

In contrast, it is in the wider narrative wherein Ammianus Marcellinus' own experiences and observations come to the fore where the majority of his reliable and accurate information on the Sasanian Persians can be found. Therefore, it can be stated with some justification that his personal experiences are more important and more

\footnotetext{
176 DIGNAS/WINTER 2007, 257; GHIRSHMAN 1962, 140-1.

177 DIGNAS/WINTER 2007, 256-7.

178 Proc. BP. 2.14.1-4; Tabarī 898. Procopius identifies this city as 'Khusro’s Antioch' and Tabarī as 'al-Rūiyya'.

1792010,139

$1801999,201$.
}

numerous that has been claimed elsewhere. His personal experiences did not lead to tall-tales but allowed Ammianus to include his first hand experiences of the Persian Empire, and show the valuable and reliable knowledge he had gained of their empire and way of life during his career.

\section{REFERENCES}

ANDO 2000

Ando, C., Imperial Ideology and Provincial Loyalty in the Roman Empire (Berkeley: University of California Press).

ATHANASSIADI-FOWDEN 1981

Athanassiadi-Fowden, P., Julian and Hellenism: An Intellectual Biography (Oxford: Oxford University Press).

\section{AUSTIN 1973}

Austin, N. J. E., In Support of Ammianus' Veracity, Historia 22, 331-335.

\section{AUSTIN 1979}

Austin, N. J. E., Ammianus on Warfare. An Investigation into Ammianius' Military Knowledge (Brussels: Latomus).

\section{BARNES 1990}

Barnes, T. D., Literary Conventions, Nostalgia and Reality in Ammianus Marcellinus. In: Clarke, G./Croke, B./ Nobbs, A. E./Mortley, R. (eds.), Reading the Past in Late Antiquity (Sydney: Australian National University Press), 59-92.

\section{BARNES 1998}

Barnes, T. D., Ammianus Marcellinus and the Representation BIVAR 1972 of Historical Reality (London: Cornell University Press).

Bivar, A. D. H., Cavalry Equipment and Tactics and the Euphrates, Dumbartion Oaks Papers 26, 271-91.

\section{BLOCKLEY 1988}

Blockley, R. C., Ammianus Marcellinus on the Persian Invasion of A.D. 359, Phoenix 42/3, 244-260.

\section{BLOCKLEY 1992}

Blockley, R. C., East Roman Foreign Policy: Formation and Conduct from Diocletian to Anastasius (Leeds: Francis Cairns).

\section{BÖRM 2007}

Börm, H., Prokop und die Perser: Untersuchungen zu den römisch-sasanidschen Kontakten in der ausgehenden BÖRM 2008 Spätantike. (Stuttgart: Franz Steiner Verlag).

Börm, H., Das Königtum der Sasaniden: Strukturen und Probleme. Bemerkungne aus Althistorischer Sicht, Klio 90, 423-443.

\section{BÖRM 2015}

Börm, H., Dynastie und Charisma im Sasanidenreich. In: Boschung, D./Hammerstaedt, J. (eds.), Das Charisma des Herrschers (Paderborn: Morphomata), 253-280.

\section{BOSWORTH 1983}

Bosworth, C. E., Iran and the Arabs Before Islam. In: Yarshater, E. (ed.), The Cambridge History of Iran 3/1. (Cambridge: Cambridge University Press).

\section{BOWSWORTH 1986}

Bosworth, C. E., Arab i: Arabs and Iran in the Pre-Islamic Period. In: Yarshater, E. (ed.), Encyclopaedia Iranica II/2 (London: Routledge), 201-203.

BROSIUS 2006

Brosius, M., The Persians: An Introduction (London: Routledge).

BROWN 1969

Brown, P., The Diffusion of Manichaeism in the Roman Empire, The Journal of Roman Studies 59, 92-103.

\section{BRUNT 1978}

Brunt, P. A., Laus Imperii. In: Garnsey, P. D. A/Whittaker, C. R (ed.), Imperialism in the Ancient World. (Cambridge: 
Cambridge University Press), 159-192.

CAMPBELL 1999

Campbell, J. B., Kataphraktoi, Der Neue Pauly 6, 339.

\section{CANEPA 2009}

Canepa, M. P. The Two Eyes of the Earth: Art and Ritual of Kingship between Rome and Iran University of California Press).

\section{CANEPA 2010}

( B e r k e l e y:

Canepa, M., Distant Displays of Power: Understanding Cross-Cultural Interaction Among the Elites of Rome, Sasanian Iran and Sui-Tang China. In: Canepa, M. (ed.), Ars Orientalis 38 (Washington D. C.: Smithsonian Institute), 121-154.

CHARLES 1998

Charles, M. B., 'Elephant ii: In the Sasanian Army', Encyclopaedia Iranica, Online Edition: http://www.iranicaonline. org/articles/elephant-ii-sasanian-army

CHARLES 2007

Charles, M. B., The Rise of the Sassanian Elephant Corps: Elephants and the Later Roman Empire, Iranica Antiqua 42, 301-346.

CHAUMONT 1989

Chaumont, M. L., Ammianus Marcellinus. In: Yarshater, E. (ed.), Encyclopaedia Iranica I/9 (London: Routledge), 977-979.

CHAUVOT 1992

Chauvot, A., Parthes et Perses dans les sources du IV siècle. In: Christol, M./Demougin, S./Duval, Y./Lepelley, C. (eds.), Institutions, société et vie politique dans l'empire romain au IV siècle ap. J.-C (Rome: École Française), 115-125.

CONRAD 1993

Conrad, L. I., Notes on al-Tabarìs History, Journal of the Royal Asiatic Society 3, 1-31.

CORBEY/LEERSSEN 1991

Corbey, R./Leerssen, J., Studying Alterity: Backgrounds and Perceptions. In: Corbey, R./Leerssen, J. (eds.), Alterity, Identity, Image: Selves and Others in Society and Scholarship (Amsterdam: Rodopi) vi-xvii.

DARYAEE 1995

Daryaee, T., National History or Keyanid History?: The Nature of Sasanid Zoroastrian Historiography, Iranian Studies 23, 129-141.

DARYAEE 2006

Daryaee, T., The Construction of the Past in Late Antique Persia, Historia Zeitschrift für Alte Geschichte 55, 493-503.

DARYAEE 2008a

Daryaee, T., Sasanian Persia: The Rise and Fall of an Empire. (London: I. B. Tauris).

DARYAEE $2008^{\mathrm{B}}$

Daryaee, T., Kingship in Early Sasanian Iran. In: Curtis, V. S./Stewart, S. (eds.), The Idea of Iran III. The Sasanian Era (London: I. B. Tauris), 60-70.

DARYAEE 2016

Daryaee, T., From Terror to Tactical Usage: Elephants in the Partho-Sasanian Period. In: Curtis, V. S./Pandleton, E./Alram, M./Daryaee, T. (eds.), The Parthian and Early Sasanian Empires: Adaption and Expansion (Oxford: Oxbow), 36-41.

DRIJVERS 1998

Drijvers, J. W., Ammianus Marcellinus on the Geography of the Pontus Euxinus, Histos 2, 168-78.

DRIJVERS 1999

Drijvers, J. W., Ammianus Marcellinus' Image of Arsaces and Early Parthian History. In: Hunt, D./Drijvers, J. W. (eds.), The Late Roman World and its Historian: Interpreting Ammianus Marcellinus (London: Routledge), 171-182.

\section{DRIJVERS 2006}

Drijvers, J. W., Ammianus Marcellinus' Image of Sasanian Society. In: Wiesehöfer, J./Huyse, P. (eds.), Ērān ud Anērān: Studien zu den Beziehungen zwischen dem Sasanidenreich und der Mittelmeerwelt (Stuttgart: Franz Steiner Verlag), 45-69.

\section{DRIJVERS 2011a}

Drijvers, J. W., A Roman Image of the 'Barbarian' Sasanians. In: Mathisen, R. W./Shanzer, D. (eds.), Romans, Barbarians and the Transformation of the Roman World (Aldershot: Ashgate), 67-76.

DRIJVERS 2011b

Drijvers, J. W., The Limits of Empire in the Res Gestae of Ammianus Marcellinus. In: Hekster, O./Kaizer, T. (eds.), Frontiers in the Roman World. Proceedings of the Ninth Workshop of the International Network Impact of Empires (Leiden: Brill), 13-30.

EDWELL 2008

Edwell, P. M., Between Rome and Persia: The Middle Euphrates, Mesopotamia and Palmyra under Roman Control (London: Routledge).

FERACO 2004

Feraco, F., Ammiano geografo: La digressione sulla Persia (23.6) (Naples: Loffredo)

FISHER 2008

Fisher, G., The Political Development of Ghassan Between Rome and Iran, Journal of Late Antiquity 1, 311-334.

FORNARA 1992

Fornara, G., Studies in Ammianus Marcellinus II: Ammianus' knowledge and Use of Greek and Latin Literature, Historia $41,420-438$.

FOWDEN 1993

Fowden, G., Empire to Commonwealth: Consequences of Monotheism in Late Antiquity (Princeton: Princeton University Press).

GAWLIKOWSKI 1985

Gawlikowski, M., Bijan in the Euphrates, Sumer 42, 15-21.

GHIRSHMAN 1962

Ghirshman, R., Iran: Parthians and Sassanians (London: Thames \& Hudson)

GREATREX 1998

Greatrex, G., Rome and Persia at War, 502-532 (Cambridge: Francis Cairns).

HARPER 2008

Harper, P. O., Image and Identity: Art of the Early Sasanian Dynasty. In: Curtis, V.S/Stewart, S (eds.), The Idea of Iran III. The Sasanian Era (London: I. B. Tauris), 71-87.

HEATHER 1999

Heather, P., The Barbarian in Late Antiquity: Image, Reality and Transformation. In: Miles, R. (ed.), Constructing Identities in Late Antiquity (London: Routledge), 234-258.

HOWARD-JOHNSTON 2008

Howard-Johnston, J., State and Society in the Late Sasanian Period. In: Curtis, V. S/Stewart, S. (eds)., The Idea of Iran: Volume III. The Sasanian Era (London: I. B. Tauris), 118-131.

HOWARD-JOHNSTON 2010

Howard-Johnson, J. The Sasanian's Strategic Dilemma. In: Börm, H./ Wiesehöfer, J. (eds.), Commutatio et Contentio: Studies in the Late Roman, Sasanian and Early Islamic Near East (Dusseldorf: Wellem), 37-70.

HUYSE 2002

Huyse, $\mathrm{Ph}$., La revendication de territoires achéménides par les Sassanides: Une réalité historique? In: Huyse, Ph. (ed.), Iran: Questions et connaissances. Actes du IVe congrés européen des études Iraniennes, organise par la Societas Iraniologica Europaea, Paris (Paris: Peeters), 297-311. 
HUYSE 2006

Huyse, Ph., Die sasanidische Königstitulatur: Eine Gegenüberstellung der Quellen. In: Wiesehöfer, J./Huyse, Ph. (eds.), Ërān ud Anērān: Studien zu den Beziehungen zwischen dem Sasanidenreich und der Mittelmeerwelt (Stuttgart: Franz Steiner Verlag), 181-201.

ISAAC 2004

Isaac, B., The Invention of Racism in Classical Antiquity (Princeton: Princeton University Press).

KALDELLIS 2004

Kaldellis, A., Procopius of Caesarea: Tyranny, History and Philosophy at the end of Antiquity (Philadelphia: University of Pennsylvania Press).

KELLY 2008

Kelly, G., Ammianus Marcellinus: The Allusive Historian (Cambridge: Cambridge University Press).

KETTENHOFEN 1984

Kettenhofen, E., Die Einordnung des Achämenidenerbes durch Ardašìr. Eine interpretation romana, Orientalia Lovaniensia Periodica 15, 177-190.

KING 1987 [1995]

King, C., The Veracity of Ammianus Marcellinus' Description of the Huns, American Journal of Ancient History 12, 77-95.

KLEISS 2001

Kleiss, W., Fortifications. In: Yarshater, E. (ed.) Encyclopaedia Iranica X/1 (Costa Mesa: Mazda Publisher), 102-106.

LANE FOX 1997

Lane Fox, R., The Itinerary of Alexander: Constantius to Julian, The Classical Quarterly 47, 239-252.

LEE 1991

Lee A. D., The Role of Hostages in Roman Diplomacy with Sasanian Persia, Historia: Zeitschrift für Alte Geschichte 40, 366-374.

LEE 1993

Lee, A. D., Information and Frontiers: Roman Foreign Relations in Late Antiquity (Cambridge: Cambridge University Press).

LEE 2013

Lee, A. D., Roman Warfare with Sasanian Persia In: Campbell, B./Tritle, L. A. (eds.), The Oxford Handbook of Warfare in the Classical World (Oxford: Oxford University Press), 708-724.

LOWE/MORYADES 1975

Lowe, J. C./Moryades, S., The Geography of Movement (Boston: Waveland).

MATTHEWS 1989

Matthews, J. F., The Roman Empire of Ammianus (London: Duckworth)

MATTHEWS 1994

Matthews, J. F., The Origins of Ammianus, The Classical Quarterly 44, 252-269.

MCDONOUGH 2011

McDonough, S., The Legs of the Throne: Kings, Elites and Subjects in Sasanian Iran. In: Arnason, J. P./Raaflaub, K. A. (eds.) The Roman Empire in Context: Historical and Comparative Perspectives (London: Wiley-Blackwell), 290-321.

MCDONOUGH 2013

McDonough, S., Military and Society in Sasanian Iran. In: Campbell, B./Tritle, L. A. (eds.), The Oxford Handbook of Warfare in the Classical World (Oxford: Oxford University Press), 601-620.

MICHALAK 1987

Michalak, M., The Origins and Development of Sasanian

MILES 1999 Heavy Cavalry, Folia Orientalia 24, 73-86.

Miles, R., Constructing Identities in Late Antiquity (London: Routledge).

\section{MITCHELL 2007}

Mitchell, S., A History of the Later Roman Empire (London: Blackwell).

MOMMSEN 1881

Mommsen, T., Ammians Geographica, Hermes 16, 602-36.

MORLEY 2016

Morley, C., Interaction and Exchange between the Roman and Sasanian Empires in Late Antiquity. In: Berthelot, H/ Boiché, A./Caltot, P. A./Diarra, M./Réveilhac, F./RomieuxBrun, E. (eds.), Le livre Vivre et penser les frontières dans le monde méditeranéen antique (Bordeaux: Ausonius), 117-126.

NOKANDEH et alii 2006

Nokandeh, J./Sauer, E./Rekavanid, H. O./Wilkinson, T./ Abassi, G. A./Schwenninger, J./Mahmoudi, M./Parker, D./ Fattahi, M./Usher-Wilson, L. S./Ershadi, M./Ratcliffe, R./ Gale, R., Linear Barriers of Northern Iran: The Great Wall of Gorgan and the Wall of Tammishe, Iran 44, 121-173.

PAYNE 2016

Payne, R., Sex, Death and Aristocratic Empire: Iranian Jurisprudence in Late Antiquity, Comparative Studies in Society and History 58/2, 519-549.

POTTER 1990

Potter, D. S., Prophecy and History in the Crisis of the Roman Empire: A Historical Commentary on the Thirteenth Sibylline Oracle (Oxford: Clarendon Press).

POURSHARIATI 2008

Pourshariati, P., Decline and Fall of the Sasanian Empire: The Sasanian-Parthian Confederacy and the Arab Conquest of Iran. (London: I. B. Tauris).

RANCE 2003

Rance, P., Elephants in Warfare in Late Antiquity, Acta Antiqua Academiae Scientiarum Hungaricae 43, 355-84.

REES 1999

Rees, R., Ammianus Satricus. In: Hunt, D./Drijvers, J. W. (eds.), The Late Roman World and its Historian: Interpreting Ammianus Marcellinus (London: Routledge), 125-137.

RICHTER 1989

Richter, U., Die Funktion der Digressionen im Werk Ammians, Würzburger Jahrbücher für Altertumswissen 15, 209-222.

\section{ROHRBACHER 2002}

Rohrbacher, D., The Historians of Late Antiquity (London: Routledge).

ROAD 1998

Road, M., Persepolitan Echoes in Sasanian Architecture: Did the Sasanians attempt to re-create the Achaemenid Empire? In: Curtis, V.S./Hillenbrand, R./Rogers, M. (eds.), Art and Archaeology of Ancient Persia: New Light on the Parthian and Sasanian Empires (London: I. B. Tauris), 1-7.

ROSEN 1970

Rosen, K., Studien zur Darstellungskunst und Glaubwürdigkeit des Ammianus Marcellinus (Bonn: Habelt).

ROSEN 1982

Rosen, K., Ammianus Marcellinus (Darmstadt: Wissenschaftliche Buchgesellschaft).

RUBIN 2000

Rubin, Z., The Sasanid Monarchy. In: Cameron, A./WardPerkins, B./Whitby, M. (eds.), The Cambridge Ancient History XIV. Late Antiquity: Empire and Successors A.D 425-600 (Cambridge: Cambridge University Press), 636-661.

SARTRE 2005

Sartre, M., The Middle East Under Rome (London: Harvard University Press).

SAUER/REKAVANDI/WILKINSON/NOKANDEH 2013

Sauer, E./Rekavandi, H. O./Wilkinson, T./Nokandeh, J., Persia's Imperial Power in Late Antiquity: The Great Wall of 
Gorgan and the Frontier Landscapes of Sasanian Iran (Oxford: Oxbow).

SHAHBAZI 2001

Shahbazi, A. S., Early Sasanians' Claim to Achaemenid Heritage, Name-ye Iran-e Bastan 1, 60-73.

SHAYEGAN 2011

Shayegan, R. M., Arsacids and Sasanians: Political Ideology in Post-Hellenistic and Late Antique Persia (Cambridge: Cambridge University Press).

SHAYEGAN 2013

Shayegan, R. M., Sasanian Political Ideology. In: Potts, D. T. (ed.), The Oxford Handbook of Ancient Iran (Oxford: Oxford University Press), 805-813.

SCHWAIGERT, 1989

Schwaigert, W., Das Christentum in Hüzistān im Rahmen der frühen Kirchengeschichte Persiens bis zur Synode von SeleukeiaKtesiphon in Jahre 410. (Marbug: Diss.)

SEECK 1906

Seeck, O., Zur Chronologie und Quellenkritik des Ammianus Marcellinus, Hermes 41, 481-539.

SHAHID 1989

Shahid, I., Byzantium and the Arabs in the Fifth Century (Washington D. C: Dumbarton Oaks Press).

SIMPSON 2000

Simpson, St. J., Mesopotamia in the Sasanian Period: Settlement patterns, arts and crafts. In: Curtis, J. (ed)., Mesopotamia and Iran in the Parthian and Sasanian Periods (London: British Museum Press), 57-66.

SMITH 1994

Smith, P. J., A Note on Ammianus and Juvenal, Liverpool Classical Monthly 19/2, 23-24.

SMITH 1999

Smith, R., Telling Tales: Ammianus' Narrative of the Persian expedition of Julian. In: Hunt, D./Drijvers, J. W. (eds.), The Late Roman World and its Historian: Interpreting Ammianus Marcellinus (London: Routledge) 89-104.

SMITH 2011

Smith, R., The Casting of Julian the Apostate 'in the Likeness' of Alexander the Great: A Topos in Antique Historography and its Modern Echos, Histos 5, 44-106.

SPENCER 2002

Spencer, D., The Roman Alexander: Reading a Cultural Myth (Exeter: University of Exeter Press)

\section{TEITLER 1999}

Teitler, H., Visa Vel Lecta? Ammianus on Persia and the Persians. In: Hunt, D./Drijvers, J. W. (eds.), The Late Roman World and its Historian: Interpreting Ammianus Marcellinus (London: Routledge), 216-223.

THOMPSON 1947

Thompson, E. A., The Historical Work of Ammianus Marcellinus (Cambridge: Cambridge University Press).

\section{TREADGOLD 2007}

Treadgold, W., The Early Byzantine Historians (London: Palgrave).

WALBANK 1983

Walbank, F., Studies in Greek and Roman Historiography (Cambridge: Cambridge University Press).

WALKER 2007

Walker, J., Iran and its Neighbours in Late Antiquity: Art of the Sasanian Empire 224-642, American Journal of Archaeology 111, 795-801.

WEISWEILER 2014

Weisweiler, J., Unreliable Witness: Failings of Narrative in Ammianus Marcellinus. In van Hoof, L./van Nuffelen, P. (eds.), Literature and Society in the Fourth Century AD: Performing Paidea, Constructing the Present, Presenting the Self (Leiden: Brill), 103-133.

WHITBY 1988

Whitby, M.,The Emperor Maurice and his Historian Theophylact Simocatta (Oxford: Oxford University Press).

WHITBY 1994

Whitby, M., The Persian King at War. In: Dabrowa, E. (ed)., The Roman and Byzantine Army in the East (Krakow: Uniwersytet Jagiellonskîego), 227-263.

WIEDEMANN 1986

Wiedemann, T. E. J., Between Men and Beasts: Barbarians in Ammianus Marcellinus. In: Moxon, I. S./Smart, J. D./ Woodman, A. J. (eds.), Past Perspectives: Studies in Greek and Roman Historical Writing (Cambridge: Cambridge University Press), 189-201.

WIESEHÖFER 1996

Wiesehöfer, J., Ancient Persia: From 550 B.C to 650 A.D (London: I. B. Tauris)

WIESEHÖFER 2007

Wiesehöfer, J., King, Court and Royal Representation in the Sasanian Empire. In: Spawforth, A. (ed.), The Court and Court Society in Ancient Monarchies (Cambridge: Cambridge University Press) 58-81.

WILSHERE 1973

Wilshere, L.E., Did Ammianus Write a Continuation of Tacitus?, The Classical Journal 68/3, 221-227.

WIRTH 1978

Wirth, G., Julianus Perserkrieg: Kriterien einer Katastrophe. In: Klein, R. (ed.), Julianus Apostata (Darmstadt: Wissenschaftliche Buchgesellschaft), 455-507.

YARSHATER 1983

Yarshater, E., Iranian National History. In: Yarshater, E (ed.), Cambridge Ancient History of Iran (Cambridge: Cambridge University Press), 359-478. 